$1-1-1934$

\title{
Control and Eradication of Brucella Abortus Infection in a Dairy Herd
}

\author{
J. H. Rietz \\ G. A. Bowling
}

Follow this and additional works at: https://researchrepository.wvu.edu/ wv_agricultural_and_forestry_experiment_station_bulletins

\section{Digital Commons Citation}

Rietz, J. H. and Bowling, G. A., "Control and Eradication of Brucella Abortus Infection in a Dairy Herd" (1934). West Virginia Agricultural and Forestry Experiment Station Bulletins. 259.

https://researchrepository.wvu.edu/wv_agricultural_and_forestry_experiment_station_bulletins/260 @ WVU. It has been accepted for inclusion in West Virginia Agricultural and Forestry Experiment Station Bulletins by an authorized administrator of The Research Repository @ WVU. For more information, please contact ian.harmon@mail.wvu.edu. 
West Virginia University Libraries

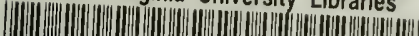

...

30802100521031 .

308021005210310 
Digitized by the Internet. Archive in 2010 with funding from

Lyrasis Members and Sloan Foundation 


\section{Control and Eradication of} Brucella abortus Infection

In a Dairy Herd

by J. H. RIETZ and G. A. BOWLING

AGRICULTURAL EXPERIMENT STATION COLLEGE OF AGRICULTURE, WEST VIRGINIA UNIVERSITY

F. D. FROMME, Director MORGANTOWN 


\section{Agricultural Experiment Station Staff}

JOHN R. TURNER, Ph.D., LL.D., Presigent of the University

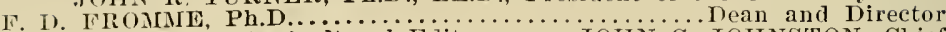

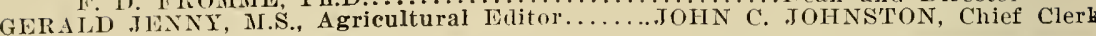

\section{AGRON()MY A ND GENETICS}

R. T. Garber, Ph.D.

Agronomist and Genetleist.

VI. H. Pierre. Ph.D.

Assuciate $A$ gronomist.

T. C. McIlvaine, Ph.D. $\dagger^{*}$

Assistant Agronomist.

G. G. Pohlinan, Ph.D.

Assistant Agronomist.

C. R. Bunlıam, Ph.D.

Assistant Geneticist

H. I. Rowley, M.S. Agr.** Seerl Analyst.

\section{ANIMLA, HUSEANDRY}

A. A. Livesay, D.Sc. Animal Husbandman.

C. Y. Wilson, M.S. Assistant Animal Husbandman.

J. H. Longwell, M.A. Assistant Animal Husbandman.

R. I. 'I'nckwiller, B.S. Agr.* Assistant Alinial Husbandman.

J. H. Rietz, D.Y.MI.** Associate Veterinarian.

E. N. Moore, D. Y.M.** Assistant Veterinarian.

\section{CHEMISTRY}

R. B. Dustman, I'h.D. Agricultural Chemist.

Chas. I. Weakley, Jr., M.A. Assistant Chemist.

T. B. Leith, M.S.** Assistant Cliemist.

I. J. Dunean, M.S. Assistant in Agricultural Chemistry.

A. H. VanI,andingham, M.S. Assistant in Agrieultural Chemistry.

\section{DAIRI HLSBANDRY}

H. O. Henderson, Ph.D. Dairy Husbandman.

L. M. 'Thurston, Ph.D. Associate Dairy Husbandman.

G. A. Bowling, M.S. Assistant Dairy Husbandman.

R. A. Ackerman, M.S.Agr. $\ddagger$ Assistant Dairy Husbandman.

\section{ENTOMOLOGY}

I. M. Peairs, Pli.D. Entomologist.

IV. E. Rumsey, B.S.** State Entomologist.

Golwin Gould, B.S. Agr. Assistant in Entomology.

\section{FARAI MANAGEMEN'T}

W. IV. Armentront, Ph.D. Associate Farm Eeonomist.

F. D. Cornell, Jr., M.S. Assistant Farm Mechanician.

IR. O. Stelzer, M.S. Assistant in Farm Economies.

\section{HOME IECONOMICS}

Rachel H. Colvell, M.A. IIome IEconomist.

Hazel C. Cameron, MI.A. Research Specialist in Nutrition.

\section{IIOR'TICUITURE}

II. E. Finowlton, Ph.D. IIorticulturist.

I. C. Westover, M.S. Assistant Horticulturist.

Ieit Verner, M.S. Assistant Horticulturist.

li. N. MeCubbin, M.A. Assistant in Horticulture.

A. P. Dye, M.S. Assistant in Horticulture.

IV. H. Childs, MI.S. Assistant in Horticulture.

\section{I'IAN'T' PA'THOLOGY}

C. R. Orton, Ph.D. Plant Pathologist.

Anthony Berg. M.S. Associate Plant Pathologist.

I. II. I،eonian, Ph.D. Associate Plant Pathologist.

F. J. Schneiderhan, Ph.D. $\uparrow \uparrow$ Associate Plant Pathologist.

\section{POUI'TRY HUSBANDRY}

'T. li. Clark, M.S Assistant in Poultry Research.

E. 'T. Wightman, M.S. Assistant in Poultry Research.

* In cooperation with the U. S. Department of Agriculture, Washington, D. C.

* In charge of the Lakin Experiment Farm, Lakin, W. Ta.

* In cooperation with the State Department of Agriculture, Charleston, WV. Va.

In charge of the Reymann Memorial Farms, Warlensville. W. Va.

$t+$ In charge of the University Experiment Farm, Kearneysille, W. Va. 


\title{
Control and Eradication of Brucella abortus Infection in a Dairy Herd
}

\author{
$B y$ J. F. RIETZ and G. A. BOWLING *
}

$\mathrm{O}$ WNERS OF MERDS of cows in which infection with Brucella abortus is found frequently ask: "What can be done to control and eradicate infections abortion?" 'They have been advised to proceed as follows: (1) Test the entire herd and either sell for slaughter all r'eactors, or separate them from the non-reactor's, establishing a completely separate and isolated herd of the reactors. (2) Test the remaining nonreactors at frequent intervals, mitil the danger of further spread of the disease from exposure to the reactors and infected premises has passed. (3) Remove all reactor's that are found after each test, selling them for slaughter or placing them in the isolation or quarantine herd. (4) Make monthly tests of the herd until at least three or four consecutive free tests have been made.

The owner usually objects to the immediate-slanghter plan because of the financial loss incurred by sacrificing otherwise valuable breeding and dairy animals at meat prices. Blood lines that have been established over long periods of time cannot be replaced if these animals are slaughtered before the proper offspring are available to carry on the breeding work. Owners object also to the complete-isolation plan because of the additional equipment in pastures, housing facilities, and labor necessary to maintain two separate herds.

To overcome partially the objections to the plans enumerated, it was attempted to control and eradicate Brucella abortus infection in the dairy herd of the West Virginia Agricultural Experiment Station by a system of frequent testing and herd management that involved parttime isolation of the reactors.

The basis for assuming that the control and eladication of Brucella Abortus infection might be accomplished by a system of herd management and testing is the fact that the causative organisms pass from the genital tract of reactors only for relatively short periods of time following parturition or abortion according to Fitch and co-workers (1) and Cotton (2).

* The authors wish to acknowledge the cooperation of Prof. H. O. Henderson. Dr. E. N. Moore, and Iessis. R. A. Ackerman, C. E. Teague, and L. F. Hermann. who assisted in various ways in the combluct of this project. 
In 1925 and 1926 the United States Department of Agriculture tested the blood of the West Virginia herd, finding 11 and 12 reactors, respectively. The testing of the blood in the laboratory of the Experiment Station was begun in January, 1928, and was repeated at irregular intervals until May, 1930, when regular monthly testing was inaugurated. Table 1 shows the results of the testing before active experimental measures were taken in the attempt to control and eradicate the (lisease in the herd.

TABLE 1-History of Brucella dibortus infection in the dairy herd before active control measures were started

\begin{tabular}{|c|c|c|c|c|c|c|}
\hline $\begin{array}{l}\text { Test } \\
\text { No. }\end{array}$ & Date & $\begin{array}{l}\text { Number } \\
\text { tested }\end{array}$ & Negative & Positive & Suspects & Remarks \\
\hline 1 & 1925 & & & 11 & & $\begin{array}{l}\text { Tested by } \\
\text { U.S. D. A. }\end{array}$ \\
\hline 2 & 1926 & & & 12 & & $\begin{array}{l}\text { Tested by } \\
\text { U. S. D. A. }\end{array}$ \\
\hline 3 & Jan. 1928 & 51 & 37 & 11 & 3 & $\begin{array}{l}\text { Tested by W. Va. } \\
\text { Exp. Station }\end{array}$ \\
\hline 4 & May, 1928 & 52 & 32 & 14 & 6 & $\begin{array}{c}\text { Tested by W. Va. } \\
\text { Exp. Station }\end{array}$ \\
\hline 5 & Nov. 1928 & 52 & 29 & 17 & 6 & $\begin{array}{c}\text { Tested by W. Va. } \\
\text { Exp. Station }\end{array}$ \\
\hline 6 & Apr. 1929 & 64 & 43 & 17 & 4 & $\begin{array}{c}\text { Tested by W. Va. } \\
\text { Exp. Station }\end{array}$ \\
\hline 7 & Nor. 1929 & 74 & 48 & 19 & 7 & $\begin{array}{l}\text { Tested by W. Va. } \\
\text { Exp. Station }\end{array}$ \\
\hline 8 & May, 1930 & 80 & 54 & 22 & 4 & $\begin{array}{l}\text { Tested by W. Va. } \\
\text { Exp. Station }\end{array}$ \\
\hline
\end{tabular}

From January, 1928, until May, 1930, the number of reactors in the herd increased from 11 to 22 under the usual herd management, no special effort being made to eliminate the reactors. During this period the number of animals tested also increased from 51 to 80 . This would indicate that the percentage increase in reactors and suspects was only 5 percent in two years. The 51 animals tested in 1928 were adult animals, and throughout the entire experiment almost all the reactors have belonged to the adult group. No effort was made during the period from 1925 to November, 1929, to test the entire herd. Even during the period May, 1930, to November, 1933, cows in advanced stages of pregnancy were sometimes omitted from the monthly test to avoid possible injury to the animal. The bulls were tested approxiniately at three-month intervals.

\section{THE TEST}

The tube-agghutination method of testing the blood was used before and during the active period of control and eradication. The blood was drawn from the jugular vein into sterile vials under approved antiseptic conditions. The vials were sloped until the blood had elotted 
and adhered to the vial wall. The vials wore then placed in the refrigerator mutil the serum had separated from the clot.

The amounts of sermm used for titrating each blood specimen for agglutination were $0.08,0.04,0.02$, and 0.01 c.c. These respective amounts of serum represent dilutions of $1: 25,1: 50,1: 100$, and $1: 200$ in the test-tube test when used with 2 c.c. of antigen (test fluid). The tubes were rearl at the end of 48 homrs with incubation at $37.5^{\circ} \mathrm{C}$.

In Table 2 is shown the interpretation of the various degrees of reactions in the dilntions used in the tests.

A partial agglutination at $1: 25$ dilution was disregarded, hut a complete agglutination at this dilution was regarded as a suspect on the first test. Upon subsequent test if no rise occurred in the titre of agolntination, this partial agghutination was regarded as not significant of infection.

A partial or complete agglntination at 1:50 dilution was regarded as a suspect on the first test. If this partial agglutination persisted in subsequent tests without change of the titre upward, it was regarded as regative.

A partial or complete agglutination at $1: 100 \mathrm{or}$ higher was regarded as positive.

TABLE 2-Interpretation of reactions in dilutions used in tests

\begin{tabular}{|c|c|c|c|c|}
\hline \multicolumn{4}{|c|}{ Dilutions } & \multirow[b]{2}{*}{ Diagnosis } \\
\hline $1: 25$ & $1: 50$ & $1: 100$ & $1: 200$ & \\
\hline -* & - & - & - & Negative \\
\hline+ & - & - & - & Negative \\
\hline+ & + & - & - & Suspect \\
\hline+ & $\mathrm{P} \ddagger$ & - & - & Suspect \\
\hline+ & + & + & + & Positive \\
\hline+ & + & + & - & Positive \\
\hline+ & + & $\mathrm{P}$ & - & Positive \\
\hline
\end{tabular}

$\ddagger \mathrm{P}=$ partial agglutination.

* The symbol "+" indicates agglutination; "- " indicates negative to agglutination.

\section{ADDITIONAL EQUIPMENT}

To isolate and control the reactors and suspects properly, it is necessary to provide a maternity ward or barn with sufficient box stalls and stanchions to accommodate the maximum number of reactors and aborters that might calve or abort during any period of eight weeks. The boxstalls were curbed on all sides to prevent drainage from one to another.

The maternity ward was so constructed that cleaning and disinfecting could be accomplished easily. The location of this building was such that the drainage and manure were diverted from the pastures, lots, and barns. 


\section{PLAN OF MANAGEMENT}

1. All animals in the herd six months of age or older were tested once monthly. This was thought necessary in order that new reactors could be detected promptly and handled in the proper manner to prevent the spread of the infection.

2. Pregnant reactors were observed once daily for indications or symptoms of abortion. This was necessary to prevent, as far as possible, abortions from taking place outside the maternity ward.

3. Reactors or other animals showing symptoms of abortion were transferred promptly to the maternity ward and confined there until the symptoms disappeared or an abortion oceurred. If an abortion ocemred the animal was retained in the ward for a period of six weeks, then returned to the lierd. If the symptoms disappeared without an abortion, the animal was retumed to the herd.

4. Reactors were transferred to the maternity ward two weeks before the normal date of parturition and were retained in the ward for a period of six weeks after parturition. If a discharge from the genito-urinary tract still existed at the expiration of the six-weeks period, that animal was retained until the discharge ceased.

Isolating the reactors two weeks before normal parturition time was thought necessary because many cows deliver normal calves a few days short of the usual gestation period.

5. All animals placed in the maternity ward were was!ed over the legs and lower portions of the body with a disinfecting solution before being returned to the general herd. This measure was taken to prevent, if possible, the mechanical carrying of the infection to the herd.

6. The boxstall or stanchion in the maternity ward in which a reactor suspect or aborter had been confined was cleaned and disinfected after the removal of any such animal, before another animal was placed therein. This was thought necessary to rednce the amount of infection in the maternity barn, thereby reducing somewhat the possibility of fresh infection available to animals added to the yuarantine.

7. Reactor's were sold for slaughter as their period of profitable production ended and as replacements could be made with heifers coming into production.

8. The manure and drainage from the maternity ward was handled through a special manure pit surrounded by a fenced lot to exclude cattle. This manure was spread upon land in tillage.

9. A pan of disinfecting solution was always kept inside the entrance to the quarantine barn, and all persons entering this barn were requested to dip the soles of their shoes in this solution before leaving the building.

10. Animals that aborted outside the quarantine barn were promptly transferred to this barn and handled as other animals in quarantine. When possible, the place where the abortion occurred outside the quarantine barn was disinfected.

11. Calves from both reactor and non-reactor dams were kept in lots, pens, or pastures entirely separate from other classes of animals during the period of milk feeding. 'This was done to prevent the 
mechanical anrying of inlection thromgh the calves' dump as a possible means of spreading infection anong susceptible animals.

At least 60 days was allowed to elapse between the and of the periorl of feeding calves on milk foon the positive animals and allowing such calves to associate with susceptible animals.

12. Aborted foxtuses and fotal placentas as well as fortal placentas firon reactol cows were bmied or burnerl.

\section{RESULTS}

In Table 3 is shown the classification of the animals in the heod by montls fiom May, 19:30, the beginning of the experiment, to $\mathrm{N}(\mathrm{x}$ vember, 193: six months after the disposal of the last reactor.

The number of aninals in the herel remainel at practically the same level throughout the experiment. During the entire period covered by this experiment, 163 individual animals were tested one or more times. Of this number 130 animals were completely and consistently negative and '2) of then were completely and consistently positive.*

In .Jnne. 19:30, three animals, numbers E-35, E-:36, and E-37 became reactors. This was one month after the beginning of the experiment. These three animals were yearling heifers that may have become infected before the beginning of this experiment.

In August, 1930, animal 192 became a reactor; this was three months after the beginning of the experiment and may possibly have resulted from exposme before the begimning of the experiment, but probably should be considered a break.

In December, 1930, animal 312 became a reactor. This animal was added to the herd in April, 1930. This was seven months after the experiment was begun and must be classed as a cross-infection or break.

In .June, 1931, animal 252 became a reactor. In April this animal gained access to the lot in which the quarantine ward manme pit was Iocated and was seen eating of the bedding from the quarantine ward. This probably accounts for the break.

In December, 1931, animal 310, an open heifer, became a reactor. The circumstance cannot be explained on the basis of available information.

Six animals that at one time were classified as positive, ceased to react and were reclassified as negative. In Table $t$ are shown the degrees of reactions of this group and the classification of the animals. The animals in this group were isolated as provided for reactors and suspects, until they were considered negative.

Five animals were classified as suspects at the time the control measmres were begun. Two of these animals were sold as suspects and three of them were later reclassified as negative. The test records of these five animals are shown in Table 5. Animal 81 of this gromp was

* The test charts of the consistently negative and consistently positive animals have been omitted from this report. 
TABLE 3-Classification of animals in the dairy herd and disposition of reactors and suspects

\begin{tabular}{|c|c|c|c|c|c|c|c|c|c|}
\hline $\begin{array}{l}\text { Test } \\
\text { No. }\end{array}$ & Date & $\begin{array}{l}\text { No. of } \\
\text { animals } \\
\text { tested }\end{array}$ & $\begin{array}{c}\text { No. of } \\
\text { animals } \\
\text { negative }\end{array}$ & $\begin{array}{c}\text { No. of } \\
\text { animals } \\
\text { positive }\end{array}$ & $\begin{array}{c}\text { No. of } \\
\text { animals } \\
\text { suspeets }\end{array}$ & $\begin{array}{c}\text { No. } \\
\text { new } \\
\text { positives }\end{array}$ & $\begin{array}{c}\text { Changes } \\
\text { pos. to } \\
\text { suspect }\end{array}$ & $\begin{array}{c}\text { Changes } \\
\text { suspect to } \\
\text { negative }\end{array}$ & $\begin{array}{l}\text { Posi- } \\
\text { tives } \\
\text { sold }\end{array}$ \\
\hline 1 & $5-30$ & 80 & 54 & 22 & 4 & 0 & 0 & 0 & 0 \\
\hline 2 & $6-30$ & 79 & 55 & 20 & 4 & 3 & 0 & 0 & 5 \\
\hline 3 & $7-30$ & 79 & 55 & 20 & 4 & 0 & 0 & 0 & 0 \\
\hline 4 & $8-30$ & 81 & 56 & 21 & 4 & 1 & 0 & 0 & 0 \\
\hline 5 & $9-30$ & 78 & 53 & 21 & 4 & 0 & 0 & 0 & 0 \\
\hline 6 & $11-30$ & 74 & 54 & 17 & 7 & 0 & 3 & 0 & 0 \\
\hline 7 & $12-30$ & 77 & 56 & 18 & 5 & 1 & 0 & 4 & 0 \\
\hline 8 & $1-31$ & 77 & 56 & 17 & 5 & 0 & 0 & 0 & 1 \\
\hline 9 & $2-31$ & 79 & 57 & 17 & 4 & 0 & 0 & 0 & 0 \\
\hline 10 & $3-31$ & 77 & 57 & 15 & 5 & 0 & 1 & 0 & 1 \\
\hline 11 & $4-31$ & 78 & 58 & 15 & 5 & 0 & 0 & 0 & 0 \\
\hline 12 & $5-31$ & 78 & 59 & 14 & 5 & 0 & 0 & 0 & 1 \\
\hline 13 & $6-31$ & 82 & 62 & 15 & 5 & 1 & 0 & 0 & 0 \\
\hline 14 & $7-31$ & 81 & 64 & 15 & 2 & 0 & 0 & 3 & 0 \\
\hline 15 & $8-31$ & 84 & 67 & 14 & 3 & 0 & 1 & 0 & 0 \\
\hline 16 & $9-31$ & 89 & 72 & 14 & 3 & 0 & 0 & 0 & 0 \\
\hline 17 & $10-31$ & 89 & 74 & 12 & 3 & 0 & 0 & 0 & 2 \\
\hline 18 & 11-31 & 84 & 71 & 10 & 2 & 0 & 1 & 0 & 1 \\
\hline 19 & $12-31$ & 86 & 73 & 10 & 2 & 1 & 0 & 0 & 1 \\
\hline 20 & $1-32$ & 85 & 72 & 10 & 2 & 0 & 0 & 0 & 0 \\
\hline 21 & $2-32$ & 83 & 71 & 8 & 3 & 0 & 1 & 0 & 1 \\
\hline 22 & $3-32$ & 82 & 71 & 8 & 3 & 0 & 0 & 0 & 0 \\
\hline 23 & $4-32$ & 82 & 73 & 6 & 3 & 0 & 0 & 0 & 2 \\
\hline 24 & 5-32 & 80 & 73 & 4 & 3 & 0 & 0 & 0 & 2 \\
\hline 25 & o-32 & 79 & 72 & 4 & 3 & 0 & 0 & 0 & 0 \\
\hline 26 & $7-32$ & 79 & 74 & 3 & 1 & 0 & 0 & 2 & 1 \\
\hline 27 & $8-32$ & 79 & 74 & 3 & 1 & 0 & 0 & 0 & 0 \\
\hline 28 & $9-32$ & 78 & 73 & 3 & 1 & 0 & 0 & 0 & 0 \\
\hline 29 & 10-32 & 78 & 73 & 3 & 1 & 0 & $\overline{0}$ & 0 & 0 \\
\hline 30 & 11-32 & 75 & 71 & 3 & 0 & 0 & 0 & 0 & 1 \\
\hline 31 & $12-32$ & 74 & 71 & 3 & 0 & 0 & 0 & 0 & 0 \\
\hline 32 & $1-33$ & 74 & 71 & 3 & 0 & 0 & 0 & 0 & 0 \\
\hline 33 & $2-33$ & 80 & 77 & 3 & 0 & 0 & 0 & 0 & 0 \\
\hline 34 & 3-33 & 73 & 71 & 2 & 0 & 0 & 0 & 0 & 1 \\
\hline 35 & 4-35 & 76 & 75 & 1 & 0 & 0 & 0 & 0 & 1 \\
\hline 36 & $5-33$ & 78 & 77 & 1 & 0 & 0 & 0 & 0 & 1 \\
\hline 37 & $6-33$ & 83 & 83 & 0 & 0 & 0 & 0 & 0 & 0 \\
\hline 38 & $7-33$ & 80 & 80 & 0 & 0 & 0 & 0 & 0 & 0 \\
\hline 39 & $8-33$ & 80 & 80 & 0 & 0 & 0 & 0 & 0 & 0 \\
\hline 40 & $9-33$ & 84 & 84 & 0 & 0 & 0 & 0 & 0 & 0 \\
\hline 41 & $10-33$ & 86 & 86 & 0 & 0 & 0 & 0 & 0 & 0 \\
\hline 42 & $11-33$ & 86 & 86 & 0 & 0 & 0 & 0 & 0 & 0 \\
\hline
\end{tabular}


TABLE 4-Reactions of positive animals that became negative

\begin{tabular}{|c|c|c|c|c|c|c|c|}
\hline $\begin{array}{l}\text { Test } \\
\text { No. }\end{array}$ & Date & $\begin{array}{c}\text { Animal } \\
168\end{array}$ & $\begin{array}{c}\text { Animal } \\
218\end{array}$ & $\begin{array}{c}\text { Animal } \\
252\end{array}$ & $\begin{array}{c}\text { Animal } \\
\text { le-36; }\end{array}$ & $\underset{10-37}{\text { Animal }}$ & $\begin{array}{c}\text { Animal } \\
280\end{array}$ \\
\hline 1 & $5-30$ & ++++ & $+t+t$ & ---- & ++-- & +-- & $++t$ \\
\hline 2 & $6-30$ & ++++ & $+t+t$ & ---- & $+++\mathrm{P}^{2}$ & $+t+t$ & $+t+t$ \\
\hline 3 & $i-30$ & $++t+$ & $++t+$ & --- & $+t+t$ & $+t+$ & ++++ \\
\hline 4 & $8-30$ & $++t+$ & ++++ & ---- & ++++ & $++t+$ & +++ \\
\hline 5 & $9-30$ & +++- & ++1 & $-\cdots-\cdots$ & ++++ & $+t+t$ & +++- \\
\hline 6 & $11-30$ & ++-- & +++ & $---\cdots$ & - - - & ---- & - - - * \\
\hline 7 & $12-30$ & $++p^{3}-$ & $+++P$ & $-\cdots-\cdots$ & +--- & +--- & $+-\ldots$ \\
\hline 8 & $1-31$ & $++P^{3}-$ & $++\mathrm{P}-$ & $---\cdots$ & $\mathrm{P}---$ & ---- & ---- \\
\hline 9 & $2-31$ & ++-- & +++- & ---- & $\mathrm{P}---$ & $-\ldots$ & ---- \\
\hline 10 & $3-31$ & ++- & $++\mathrm{P}-$ & ---- & $-\cdots-$ & - - - & $-\cdots--$ \\
\hline 11 & $4-31$ & ++++ & $++\mathrm{P}-$ & $-\cdots--$ & ---- & $--\cdots$ & ---- \\
\hline 12 & $5-31$ & ++++ & ++-- & - - - & ---- & +--- & - - - \\
\hline 13 & $6-31$ & $t++\mathrm{P}$ & +++ & ++++ & $\ldots-\cdots$ & $+-\cdots$ & $---\cdots$ \\
\hline 14 & $7-31$ & $++P-$ & ++- & $+t+t$ & $+---\dagger$ & $+\mathrm{P}--+$ & $\ldots \ldots+$ \\
\hline 15 & $8-31$ & $++\ldots{ }^{*}$ & $+\ldots$ & $+++\mathrm{P}$ & $+\cdots-$ & $-\ldots-$ & $--\cdots$ \\
\hline 16 & $9-31$ & ++-- & $++\mathrm{P}-$ & $+++\mathrm{P}$ & +--- & $+--\cdots$ & $--\cdots$ \\
\hline 17 & $10-31$ & $++\cdots$ & ++- & ++-- & $+\ldots-$ & +--- & ---- \\
\hline 18 & $11-31$ & ++-- & $+t+-$ & $+\mathrm{P}--^{*}$ & +--- & $+--\cdots$ & $-\ldots$ \\
\hline 19 & $12-31$ & ++-- & +++ & $+\mathrm{P}--$ & +-- & +--- & ---- \\
\hline 20 & $1-32$ & $++\cdots$ & $++\mathrm{P}-$ & $+\mathrm{P}--$ & +--- & $+\cdots$ & $-\cdots--$ \\
\hline 21 & $2-32$ & $+\mathrm{P}-$ & $++--^{*}$ & +--- & $+-\ldots$ & +--- & $--\cdots$ \\
\hline 22 & $3-32$ & ++-- & ++-- & +--- & +--- & +--- & - - - \\
\hline 23 & $4-32$ & ++-- & $+\cdots-$ & $\mathrm{P}---$ & +--- & $+-\cdots$ & $--\cdots$ \\
\hline 24 & $5-32$ & ---- & $+\mathrm{P}--$ & $\mathrm{P}-\ldots+$ & +--- & +--- & $-\cdots--$ \\
\hline 25 & $6-32$ & ++-- & $+\cdots-$ & $P---$ & +--- & $++\cdots-$ & $-\cdots-$ \\
\hline 26 & $7-32$ & $++\ldots+$ & ++-- & $-\ldots-$ & +--- & +--- & $\ldots \ldots$ \\
\hline 27 & $8-32$ & ++-- & $+\cdots-t$ & ---- & +--- & +--- & $-\cdots-二$ \\
\hline 28 & $9-32$ & $+--\cdots$ & +--- & $-\cdots-$ & $+-\cdots-$ & +--- & $\ldots--1$ \\
\hline 29 & $10-32$ & +--- & $+\mathrm{P}$ & ---- & +--- & +-- & $\ldots-\cdots$ \\
\hline 30 & $11-32$ & +--- & +--- & $--\ldots-$ & ---- & ---- & ---1 \\
\hline 31 & $12-32$ & $+\mathrm{P}--$ & $+\mathrm{P}-\cdots$ & +--- & $--\cdots-$ & $-\cdots-$ & $\ldots-$ \\
\hline 32 & $1-33$ & +--- & $+\mathrm{P}--$ & +--- & ---- & $-\ldots--$ & $--\cdots$ \\
\hline 33 & $2-33$ & ++-- & $+\mathrm{P}-$ & +--- & $+-\ldots$ & ---- & -二工二 \\
\hline 34 & $3-33$ & ++-- & +--- & $+-\cdots-$ & +--- & sold & --- \\
\hline 35 & $4-33$ & $+\mathrm{P}--$ & $+\cdots-$ & ---- & sold & & - - - - \\
\hline 36 & $5-33$ & +--- & +--- & ---- & & & $---\cdots$ \\
\hline 37 & $6-33$ & +--- & +--- & ---- & & & - - - \\
\hline 38 & $7-33$ & +--- & +--- & ---- & & & $-\ldots-\cdots$ \\
\hline 39 & $8-33$ & $\mathrm{P}-\ldots$ & +--- & ---- & & & - - - \\
\hline 40 & $9-33$ & +--- & +--- & ---- & & & $-\cdots-$ \\
\hline 41 & $10-33$ & +--- & $+\cdots-$ & ---- & & & -二-一 \\
\hline 42 & 11-33 & $\mathrm{P}---$ & ---- & $--\cdots-$ & & & ---- \\
\hline
\end{tabular}

*onsidered suspect. $\quad \mathrm{P}=$ Partial agglutination.

$\dot{*}$ Corsisidered negative. 
TAвLE 5-Degree of reaction of the suspect group

\begin{tabular}{|c|c|c|c|c|c|c|}
\hline $\begin{array}{l}\text { Test } \\
\text { No. }\end{array}$ & Date & $\begin{array}{c}\text { Animal } \\
40\end{array}$ & $\underset{81}{\text { Animal }}$ & $\begin{array}{c}\text { Animal } \\
116\end{array}$ & $\underset{147}{\text { Animal }}$ & $\underset{256}{\operatorname{Animal}}$ \\
\hline 1 & $5-30$ & ++-- & +--- & +--- & ++-- & $\mathrm{P}---$ \\
\hline 2 & $6-30$ & $+\mathrm{P}--$ & $+\mathrm{P}--$ & $+\mathrm{P}--$ & $+\mathrm{P}--$ & $+\mathrm{P}--$ \\
\hline 3 & $7-30$ & $++\mathrm{P}-$ & $++\mathrm{P}-$ & $+\mathrm{P}--$ & +--- & $+\mathrm{P}--$ \\
\hline 4 & $8-30$ & $+\mathrm{P}--$ & $++\mathrm{P}-$ & $+\mathrm{P}--$ & $+\mathrm{P}--$ & $+\mathrm{P}--$ \\
\hline 5 & $9-30$ & $+\mathrm{P}-\cdots$ & $+\mathrm{P}--$ & +--- & +--- & $P---$ \\
\hline 6 & $11-30$ & $\mathrm{P}-\ldots$ & $+\mathrm{P}-\ldots$ & +--- & $\mathrm{P}---$ & $\mathrm{P}---$ \\
\hline$i$ & $12-30$ & $+\mathrm{P}--$ & $+\mathrm{P}--$ & $+\mathrm{P}--$ & $\mathrm{P}---$ & +--- \\
\hline 8 & $1-31$ & $+\mathrm{P}--$ & $++\mathrm{P}-$ & +--- & $+\mathrm{P}--$ & ---- \\
\hline 9 & $2-31$ & +--- & $+\mathrm{P}-二$ & +--- & $+\mathrm{P}-{ }^{*}$ & $\mathrm{P}--{ }^{*}$ \\
\hline 10 & $3-31$ & +--- & $+\mathrm{P}--$ & +--- & $+\mathrm{P}--$ & ---- \\
\hline 11 & $4-31$ & +--- & +--- & +--- & +--- & ---- \\
\hline 12 & $5-31$ & +--- & +--- & $\mathrm{P}---$ & +--- & ---- \\
\hline 13 & $6-31$ & $+\mathrm{P}--$ & $+\mathrm{P}-$ & ++-- & ++-- & +--- \\
\hline 14 & $7-31$ & $+\mathrm{P}--$ & ++-- & $+\mathrm{P}-\cdots$ & $+\mathrm{P}--$ & $+\mathrm{P}--$ \\
\hline 15 & $8-31$ & $+\mathrm{P}--$ & $++\cdots-$ & ++-- & $+\mathrm{P}--$ & $\mathrm{P}---$ \\
\hline 16 & $9-31$ & $+\mathrm{P}--$ & ++-- & $++-二$ & $++\cdots$ & $+--\cdots$ \\
\hline 17 & $10-31$ & $+\mathrm{P}--$ & $+\mathrm{P}--$ & $\mathrm{P}---$ & ---- & +--- \\
\hline 18 & $11-31$ & $+\mathrm{P}--$ & ++-- & sold & ++-- & $+\mathrm{P}--$ \\
\hline 19 & $12-31$ & $+\mathrm{P}--$ & ++-- & & $++\cdots-$ & $+-\ldots$ \\
\hline 20 & $1-32$ & $+\mathrm{P}-\mathrm{C}^{*}$ & ++-- & & ++-- & $+\mathrm{P}--$ \\
\hline 21 & $2-32$ & $+\mathrm{P}--$ & $+\mathrm{P}--$ & & $+\mathrm{P}--$ & +--- \\
\hline 22 & $3-32$ & $+\mathrm{P}--$ & $+\mathrm{P}--$ & & $+\mathrm{P}--$ & $\mathrm{P}-\cdots-$ \\
\hline 23 & $4-32$ & $+\mathrm{P}--$ & $+\mathrm{P}--$ & & $+\mathrm{P}--$ & +--- \\
\hline 24 & $5-32$ & $+\mathrm{P}--$ & $+\mathrm{P}--$ & & $+\mathrm{P}--$ & +--- \\
\hline 25 & $6-32$ & $+\mathrm{P}--$ & ++-- & & $+\mathrm{P}--$ & +-- \\
\hline 26 & $7-32$ & ++-- & ++-- & & $++-\cdots$ & $+-\ldots$ \\
\hline 27 & $8-32$ & ++-- & $+\mathrm{P}--$ & & ++-- & +--- \\
\hline 28 & $9-32$ & +--- & $+\mathrm{P}--$ & & ++-- & $\mathrm{P}---$ \\
\hline 29 & $10-32$ & +--- & $+-\ldots$ & & $++-\cdots$ & +--- \\
\hline 30 & 11-32 & +--- & $+\mathrm{P}--$ & & ++-- & $+\cdots$ \\
\hline 31 & $12-32$ & $+\cdots-$ & sold & & $+\mathrm{P}--$ & +--- \\
\hline 32 & $1-33$ & +--- & & & $+--\cdots$ & $+\mathrm{P}-$ \\
\hline 33 & $2-33$ & $+\mathrm{P}--$ & & & ++-- & $-\ldots$ \\
\hline 34 & $3-33$ & $+\mathrm{P}--$ & & & ++-- & ---- \\
\hline 35 & $4-33$ & $+\mathrm{P}--$ & & & $+\mathrm{P}--$ & $-\cdots$ \\
\hline 36 & $5-33$ & $+\mathrm{P}--$ & & & ++-- & ---- \\
\hline 37 & $6-33$ & $+\mathrm{P}--$ & & & ++-- & ---- \\
\hline$: 35$ & $7-33$ & +--- & & & +--- & ---- \\
\hline 39 & $8-33$ & $+\mathrm{P}--$ & & & $+\mathrm{P}--$ & $---\cdots$ \\
\hline 40 & $9-33$ & $+\mathrm{P}--$ & & & ++-- & - - - \\
\hline 41 & $10-33$ & +--- & & & ++-- & $-\cdots--$ \\
\hline 42 & $11-33$ & $--\cdots$ & & & $+\mathrm{P}--$ & ---- \\
\hline
\end{tabular}

* considered negative. 
a bralchor before May 1930. 'This aceounts for the lomg period of tine this animal was classed as a suspect.

In Table 6 are slown the reasons for the olinination of the reactors and suspects from the herd. 'I'wo amimals were eliminated to terninate the experiment; all otber animals eliminated showerl sulficient cause for their elinination, even if they load not been reactos's.

TABLE 6-Disposilion of rearlors and suspects

\begin{tabular}{|c|c|c|}
\hline $\begin{array}{c}\text { No. of } \\
\text { animals }\end{array}$ & Classification & Reasons for elimination or reclassification \\
\hline 8 & Reactor & Poor producers \\
\hline 6 & React or & Failed to conceive \\
\hline 2 & Reactor & Two blind quarters each \\
\hline 1 & Reactor & Tumor on the eyeball \\
\hline 1 & Reactor & Died at time of parturition \\
\hline 1 & Reactor & Neck broken (accidental) \\
\hline 1 & Reactor & Unbred heifer-sold \\
\hline 6 & Reactor & In the herd as non-reactors and classified as negative \\
\hline 2 & Reactor & Eliminated to terminate experiment \\
\hline 1 & Suspect & Old \\
\hline 1 & Suspect & Failed to conceive \\
\hline 3 & Suspect & In the herd as non-reactors and classified as negative \\
\hline
\end{tabular}

TABLE 7-Calving record of the dairy herd

\begin{tabular}{|c|c|c|c|c|}
\hline \multirow[b]{2}{*}{ Classification } & \multicolumn{4}{|c|}{ Year } \\
\hline & 1930 & 1931 & 1932 & $1933^{*}$ \\
\hline Negative cows dropping living calves, full-time gestation & 25 & 25 & 40 & 23 \\
\hline Negative cows dropping dead calves, full-time gestation & 2 & 1 & 1 & 0 \\
\hline Negative cows aborting & 2 & 2 & 1 & 1 \\
\hline Suspect cows dropping living calves, full-time gestation & 1 & 5 & 3 & 0 \\
\hline Suspect cows dropping dead calves, full-time gestation & 0 & 0 & 0 & 0 \\
\hline Suspect cows aborting & 0 & 0 & 0 & 0 \\
\hline Positive cows dropping living calves, full-time gestation & 12 & 2 & 3 & 0 \\
\hline Positive cows dropping dead calves, full-time gestation & 1 & 1 & 0 & 0 \\
\hline Positive cows abosting & 5 & 3 & 0 & 0 \\
\hline
\end{tabular}

* January, 1933, to June 30, 1933.

The ealving record of the herd from January 1, 1930, to June 30, 1933, is shown in Table 7. Six abortions as well as four dead calves of full-time gestation occurred in the negative group, and eight abortions and two dead calves of full-time gestation occurred in the positive group. The negative group averaged 66.3 animals tested per month, while the positive group averaged 10.4 animals tested per month.

During the period covered by this work, 37 isolations were made in the quarantine barn on account of parturitions and abortions. Of this number 31 were reactors and suspects and 6 were negatives. 
The bulls were first tested in November, 1928, and from that time forward a total of eleven bulls were tested in the herd. One bull reacted on the first test and remained a consistent reactor until September, 1931, when he was sold for slaughter. This animal was used only for breeding reactor cows.

\section{DISCUSSION}

The success of the plan described in this report and executed in the dairy herd of the West Virginia Agricultural Experiment Station depends upon the ability of the management to carry out many details. Herd owners should have their equipment examined and checked by a competent person before attempting to control and eradicate abortion disease by this method.

\section{SUMMARY}

There were 22 reactors in the West Virginia Agricultural Experiment Station dairy herd on May 1, 1930, the beginning of the experiment.

During the time covered by this experiment seven additional reactors appeared in the herd. Three of these appeared the month following the beginning of the experiment. One animal gained access to the quarantined manure pit. The remaining three breaks cannot satisfactorily be accounted for.

Twenty-two reactors were sold for slaughter, six became nonreactors and were in the herd at the termination of the experiment, and one was reclassified as a suspect and sold for slaughter while so classified.

One reactor only was retained in the quarantine longer than six weeks following parturition. This animal was retained eight weeks on account of a vaginal discharge.

All reactors had been eliminated from the herd by May, 1933, and the herd was considered clean at that time.

Replacements were made from heifers produced in the herd, excepting where purchase was made for new blood lines.

Brucella abortus infection was eliminated from the dairy herd of the West Virginia Agricultural Experiment Station by the prescribed system of frequent testing and herd management.

\section{LITERATURE CITED}

(1) Fitch, C. P., Delez, A. L., and Boyd, W. L.

DURATION OF THE ELIMINATAION OF BACTERIUM ABORTUS BANG IN THE VAGINAL AND UTERINE DISCHARGES OF INFECTED CATTLE. Jour. A. V. M. A. LXXVI n. s. 29 (5) : 680-685. 1930.

(2) Cotton, W. E.

abortion disease in Cattle. Jour. A. V. $M . A$. LV n. s. 8 (5) : 504-528. 1919 . 

